\title{
THE CONCEPTION OF POST-INDUSTRIAL (INFORMATION) SOCIETY AND MARXIST PHILOSOPHY IN RUSSIA
}

\section{S.V. Orlov}

Saint-Petersburg State University of Aerospace Instrumentation, Saint-Petersburg, Russia e-mail: orlov5508@rambler.ru

\author{
N.A. Dmitrenko \\ Saint Petersburg National Research University of Information Technologies, Mechanics and Optics, Saint-Peters- \\ burg, Russia \\ e-mail: nadmitrenko@corp.ifmo.ru
}

Abstract. In this study we investigate the Marxist approach to information society which helps to correct its description as a society of knowledge, where mental labor displaces manual labor. The new type of labor is a special form of general work discovered by K. Marx. It deals with material virtual reality (information, software products, active content). Virtual reality is a new form of objective reality which interacts with subjective reality closer than other forms of matter. Virtual reality acquires some qualities similar to the main qualities of subjective reality. It is possible to call them "quasi ideality" and "quasi subjectivity". Computer labor is the creation of abstract material structures which form virtual reality. Consequently, there is no "dematerialization" of labor in information society. The new form of matter, created by humans and the new forms of material labor (general work) both influence such social processes as class struggle, interaction between different forms of labor, etc.

Keywords: information society, Marxist philosophy, virtual reality.

Cite as: Orlov, S.V., Dmitrenko, N.A. (2019) [The Concept of the Post-Industrial (Information) Society and Marxist Philosophy in Russia]. Intellekt. Innovatsi. Investitsii [Intellect. Innovation. Investments]. Vol. 3, p. 131-138. DOI:10.25198/2077-7175-2019-3-131.

\section{КОНЦЕПЦИЯ ПОСТИНДУСТРИАЛЬНОГО (ИНФОРМАЦИОННОГО) ОБЩЕСТВА И МАРКСИСТСКАЯ ФИЛОСОФИЯ В РОССИИ}

\section{С.В. Орлов}

Санкт-Петербургский государственный университет аэрокосмического приборостроения, Санкт-Петербург, Россия

e-mail: orlov5508@rambler.ru

\section{Н.А. Дмитренко}

Санкт-Петербургский национальный исследовательский университет информационных технологий, механики и оптики, Санкт-Петербург, Россия e-mail: nadmitrenko@corp.ifmo.ru

Аннотация. В статье рассматривается марксистский подход к информаџионному обществу, дающий возможность скорректировать описание последнего как общества знания, в котором физический труд замещзается трудом умственным. Новый тип труда является специфической современной формой всеобщего труда (general work), открытого еще К. Марксом. Современный всеобщий труд имеет дело с материальной виртуальной реальностью (информация, программный продукт, контент файлов). Виртуальная реальность - это новая форма объективной реальности, наиболее близко и тесно взаимодействуюшая с субъективной реальностью. Виртуальная реальность обладает некоторыми специфическими свойствами, внешне напоминаюшими свойства субъективной реальности, сознания. Их предлагается назвать «квазиидеальностью» и «квазисубъективностью». Компьютерный труд - это создание абстрактных материальных структур, образующих основу виртуальной реальности. В информационном обществе не происходит какой-то «дематериализаиии» труда. Новая, созданная человеком форма материи и новые формы материального труда (всеобщий труд) в конечном итоге влияют на такие социальные процессы, как классовая борьба и разнообразные общественные движения, взаимодействие различных видов труда в технологических процессах и т. $n$. 
Ключевые слова: информаџионное общество, философия марксизма, виртуальная реальность.

Для цитирования: Орлов С.В., Дмитренко Н.А. Концепция постиндустриального (информационного) общества и марксистская философия в России // Интеллект. Инновации. Инвестиции. - 2019. - № 3. C. 131-138. DOI:10.25198/2077-7175-2019-3-131.

\section{Introduction}

Russian Marxist philosophers in the former Soviet Union usually asserted that there were a deep contradiction between the materialistic interpretation of history and the conception of post-industrial (information) society. Accordingly, the post-industrial society conception was of no use in Marxist research. In this connection it is worth mentioning a remark that D. Bell made in the introduction to his classical work "The Coming of Post-industrial Society". Bell could not agree with a characteristic of his views as "antiMarxist" and called himself post-Marxist because he used a lot of Marxist notions of society [2, p. XCI]. Further comments showed that the classic of post-industrialism rejected the conception of historical materialism - for example, in his idea of society as totality of three spheres (techno-economic system, political system and culture), where none of them determined the others $[2, \mathrm{p}$. XCIX]. But in the XXI century the understanding of an important role of post-industrial conception in the studying of modern society development prevails in Russia. One of the pioneers of the new approach is a Russian economist Vladislav L. Inozemtsev [8]. A deeper analysis of modern society and theories of its nature becomes more convincing owing to the comparison of the post-industrial (or information) society conception and the traditional historical materialism ideas.

$\mathrm{K}$. Marx is known to have written in the very beginning of "Capital": "The wealth of those societies in which the capitalist mode of production prevails, presents itself as 'an immense accumulation of commodities', its unit being a single commodity" [10, p. 43]. Much the same situation is seen in modern information society: it presents itself as an immense accumulation of information, software products and various types of equipment which are used to process information. The main problem is to understand the laws of this new society development and to reveal the similarity and difference between this new type of society and the previous one.

The great changes, which the information society brings, touch upon all levels of being, with the deepest ones being included. First, it is possible to point out some changes at the ontological level of being, which have not been exactly realized yet. Second, there are deep changes at the level of human cognition and practice, in the ways of their understanding and their labor. And third, these changes bring to existence a lot of new phenomena in different spheres of ordinary life. The examination of these levels from the viewpoint of Marxist philosophy helps to explain some fundamental features of post-industrial, or information society.

\section{The Level of Ontology}

From the ontological point of view, we can ascertain that the firm basis of information society consists of such special phenomena as information, virtual reality, software, etc. Information had existed in nature before the appearance of humankind, but virtual reality and software arose only in the XX century. How can we interpret their connections with the traditional concepts of philosophy, namely those of matter, consciousness, ideal, evolution, human being? Can these new realities improve our understanding of fundamental philosophical problems? And it is important to analyze even more: do these new phenomena and events bring any essential changes into the objective reality itself? Do such changes demand at least a thorough study and evaluation?

Nowadays there exists a widespread opinion that information is a non-material, ideal phenomenon. This approach is popular especially among some researchers in the field of social information. On the one hand, it provokes some serious objections and, on the other hand, it stimulates to carry out a special analysis. That is the analysis of correlation between virtual reality and the basic structures of the material world. The social level of information processes is certain to be closely connected with human knowledge. But on the basic physical level information is described as a measure of arrangement and organization of material systems.

At the beginning of the XX century the main Russian follower of K. Marx, V.I. Lenin, politician and philosopher, analyzed the philosophical problems of a famous crisis in physics in his book "Materialism and Empirio-Criticism". He gave the definition of "matter" as "a philosophical category denoting the objective reality which is given to human by his sensations, and which is copied, photographed and reflected by our sensations, while existing independently of them" $[9$, p. 131]. He proved that there was no other fundamental reality in the world except matter and consciousness, which had been already comprehended by great philosophers of Ancient Greece. This approach has preserved its value up to date. If information is non-material, it should be admitted that it is a spiritual, mental phenomenon. Hence the mental processes have to take place on every flash drive and compact disc when we record information on them. But modern psychology never finds out that a computer possesses any elements of psychics. Consequently, the resemblance of information and mental processes should be explained in some other way.

In my view, a modern attempt of information interpretation as a spiritual phenomenon is logically con- 
nected with the technical and spiritual processes in post industrial (or information) society. There is, in fact, some crisis in the interpretation of matter and its interaction with consciousness (a new aspect of mind-body problem), which originates from qualitatively complicated mechanism of interaction between material and spiritual events. This modern crisis partly resembles the situation in physics at the beginning of the XX century mentioned above. At the same time the modern crisis is closely connected not with some scientific discoveries themselves, but with technical inventions which are based on these discoveries and produce a revolution in information technologies (computers, nets, software products, active content, etc.).

Overcoming the modern crisis can be achieved by defining the conceptions of matter and spirit more accurately and by comparing them with some new phenomena of scientific cognition (e.g. information, virtual reality, software products, active content), in which the interaction between matter and spirit appears to be most complicated.

There really exist some reasons for bringing together information, virtual reality, on the one side, and subjective reality, on the other. This problem can be examined better if software products are studied as a special form of reality.

The functions of the computer include a partial replacing of an ideal mental image by a software product in the processes of regulation and control in material production, while modeling the mental process at the material, even physical level. The software product becomes quite a new modification of artificial material phenomena. It provides for some new mechanism of interaction of material and ideal realities. The ideal image exists only on the material substratum, i.e. the human brain. While transmitting some functions of regulation and control to the computer, which uses software, a programmer creates a new material phenomenon, which seems to be a simplified material copy of an ideal mental image. Such an analogy of the mental image - the software product - begins to carry out some functions of the ideal mental image, but it differs from this image in the main point: any software belongs to material reality.

The degree of resemblance between software and the mental image can be defined by comparing their basic characteristics. The main features of the mental image are thought to be its ideality and subjectivity. While modeling these features of ideal mental images by means of material, physical processes, software acquires some resemblance with mental images. This resemblance can be summarized by means of the following new notions: quasi ideality and quasi subjectivity (Orlov S. V. 2013. P. 88-91).

Quasi ideality. The content of the mental image does not consist of characteristics of material substratum of thought (the brain), but of the characteristics of an external object which any individual recognizes.
Psychology explains the content of mental image not in the terms of its nervous substratum, but in the terms of external world. The software product is also created for the purpose of reflecting the characteristics of external objects and regulating machinery influence over them. Humans understand and explain the software product not in terms of dipoles and charged particles, but in terms of external world (as in case of human mind). So there is an important analogy between the mental image and the software product. But at the same time there is a great difference between them: the software product remains entirely a material, physical phenomenon. According to one of the most successful definitions, the ideal image is a way of existence of external object characteristics which are separated from their own natural substratum, namely the existence of these characteristics on the basis of a special universal material substratum (i. e. the human brain) [16, p. 12]. In computers producing virtual reality some kind of universal material substratum is also used, i.e. a data carrier. Any information which the individual possesses can be recorded on this carrier. Therefore it becomes possible to compare the data carrier as universal substratum, which can record information, with the human brain. But the universality of such a carrier is not absolute, in contrast to the universality of humankind and the human brain. The universality of the data carrier is provided by the universality of human cognition and their material labor activity. The programmer endows software with some superficial features of an ideal form of reflection, which no other material object possesses. The software product expresses the content of some other material substrates and some forms of human activity, keeps information about them, remaining an entirely material formation itself. It is simpler than the ideal images. It is a simplified physical model of an ideal human thought, that is to say a quasi ideal phenomenon.

Quasi subjectivity. Subjectivity of thought is its escape from outside observation, its existence only for the reflecting subject, its impossibility to be transmitted to any other subject. If the ideal phenomena are utterly subjective in their forms (but, certainly, not in their objective content), the software product possesses only some outward characteristics of the ideal image. It is inaccessible for human perception if some special equipment is not used. Its inner content is usually hidden and not observable for anybody except the programmer, who is able to use special codes. Subjectivity of the ideal image arises from the absolute impossibility of transmission this inner ideal image from the brain to any other substance. Quasi subjectivity of the software product results from some technical difficulties in decoding its inner material structure by an outside observer.

Thus the software product appears to be a qualitatively new class of material objects created by humans as a part of the so called "second nature" ("techno- 
sphere", "noosphere") at the post-industrial stage of social progress. According to its functions and outer manifestations, the software product stands closer to human thinking than any other component of the material technical production system. The other components of the technical system (machinery) have to be coordinated with physical and even mechanical resources of humans while the software product ought to be coordinated with the potentialities of their psychics. Software makes longer the way from the ideal image to its materialization in the productive labor process, as well as any mechanical instrument made longer the way from the human hand to the subject of human labor at the dawn of civilization. Consequently, the ideal image, i.e. the goal of labor activity, materializes in the labor process not directly but through an intermediate stage the software product, which controls the functions of machinery and seems to be a "thought-resembling", quasi ideal, quasi subjective material image. Only owing to software product functioning, new classes of soluble theoretical and practical problems as well as some new spheres of labor activities have appeared. They are space exploration and nuclear energy, new systems of information control and transmission, online business, telecommuting, etc.

Virtual reality can be described as totality of special material structures and processes which are developed on the so called "matrix" of ideal, spiritual reality. This new form of objective reality possesses special qualities - quasi ideality and quasi subjectivity. Hence this reality is capable of modeling any spiritual, mental processes in more exact and detailed way than other well-known forms of matter can. Virtual reality is created by people as an artificial modification, a new sphere of objective reality, a material mediator, which allows improving the influence of consciousness on matter. In the future the way of objective and subjective reality interaction development is supposed to consist in forming some mediatory links (structures). These links will express the content of the one reality with the help of the other in an increasingly correct way. They will form new opportunities in the sphere of more productive and complicated labor and advanced technologies. This process is not only the cognition of something which has already existed but also the formation of new levels of material and spiritual realities in human labor activities. In summary, it is an ontological process, the creation of a new, human-made form of matter.

\section{The Level of Human Cognition and Labor}

The basic changes in the relations between humans and nature in information society are illustrated in the scheme (figure 1).

The animal always influences nature directly by means of its body without any mediation. Man in ancient times influenced nature in the primitive labor process by means of a special mediator - primitive instruments (tools). Later on more complicated pieces of equipment appeared. These are machines and automatic equipment. Finally, in information society a new connective link between people and automatic equipment comes to existence - this is virtual reality, which consists of information, nets, information utility networks, software, etc. The computer labor becomes more complicated in comparison with the traditional forms of industrial labor, which does not involve such a specific component as the work with virtual reality. What is the essence of this new type of labor, so important for information society development?

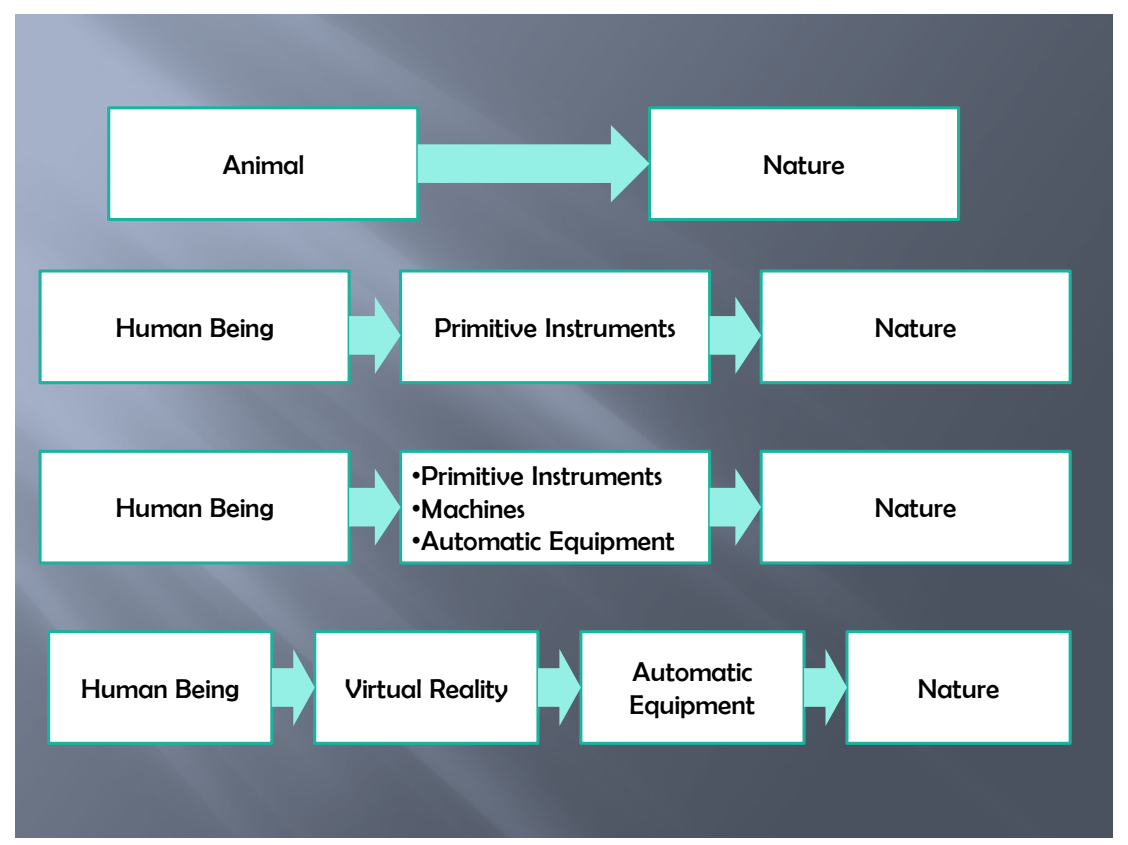

Figure 1. 
The majority of Russian philosophers are of the opinion that in future society development mental labor will gradually take the place of manual labor. For example, according to the author of a famous monograph "Labor" Irina I. Changli, the labor in communist society is dedicated mainly to the production of knowledge [5, p. 49]. Well-known experts in the problems of modern capitalism Alexander V. Buzgalin and Andrei I. Kolganov assume that in post-industrial society manual labor is being replaced by a new phenomenon - creative power. The sphere of creative power lies 'to the other side' of material production sphere. A special kind of post-material activity is replacing traditional material labor and activity [4, pp. 55-138]. This trend of thoughts is similar to the approach of Yoneji Masuda, who wrote: "In the information society the leading structures will be the intellectual industries, the core of which will be the knowledge industries" [13, p. 31]. T. Dlugach (Institute of Philosophy, Russian Academy of Sciences) considers that general work is "an integral creative labor which cannot be divided into mental and manual labor", but at the same time she calls this kind of labor "general spiritual work" [6, pp. 23, 24]. These conceptions imply some kind of "dematerialization" of labor in the future.

But some philosophers of Marxist orientation have a different opinion. S. Sayers explains that labor process does not become "non-material" if a worker uses a computer to control technological processes. Their labor remains material and produces material results [18, pp. 43-483]. In Russia this idea is promoted, for example, in the works of Perm University School of materialistic philosophy. The main idea consists in recognition that not only worker's labor remains material, but it is possible to consider programmer's activity as a special new kind of material labor, which is neither manual nor mental in the traditional sense of these terms. According to this conception, computer labor which deals with the software product, is a modern type of a special kind of labor discovered by Karl Marx - general work [11, p. 530; 12, p. 86]. Marx described material general work as automatic labor, which uses science and new nature forces and gives great opportunities to develop the universal creative powers of humans (15, pp. 207-208]. The most complicated modern form of universal labor is computer labor, which consists in production of information [15, pp. 223-224]. In this case, information appears to be some material structure; it exists in the computer not in a mental, spiritual form, but as some regulation of fine structures (charged particles). They can be recognized by humans and then begin acting as a basis of some spiritual, non-material form of information and human knowledge. But the information in a computer, which is a material technical system, remains abstract material structures $[15$, p. 224), created by material particles. Software, records and active content are only some sequence formed by means of charged particles.
Thus computer labor can be qualified as a construction of abstract material structures. On the one hand, despite their microscopic dimensions these structures act in the labor process similar to any other component of the whole system of material equipment (tools). Abstract material structures consist of natural substances (charged particles) and they influence like special fine tools on a computer, then on transfer mechanism, on macroscopic machine tools and, finally, on the object of labor. On the other hand, the attribute of "abstractness" is a main difference between structures mentioned above and all other components of the working process. Machinery exists in many concrete, different forms because it corresponds to different laws of nature and technological processes which affect different objects of labor. Abstract material structures can regulate and direct any technological process and possess any information content. Hence the production and application of these structures become the universal type of labor - general work which is widely spread in the computer era and differs in its essence from all previous forms of labor.

An important difference between manual, mental labor and general work can be described by the comparison of their products. Thus a machine tool is a product of manual labor and it can act in the process of material production as a component of the whole system of machines. A book is a product of mental labor and also a material thing. But this thing cannot act as a part of material system of production, its value consists in the mental content which the book involves (and which can influence material processes only if humans materialize, embody this mental content by means of some machinery). In contrast to these two types of labor, software products, which seem to be a product only of mental labor, are used, in fact, as a fine tool, a material part of any modern production system. Software products can act in material-production sphere not only as a source of knowledge (as the book can), but as a material agent, a real part of the material production system. This capacity brings software products closer to a machine tool and makes the programmer's labor a special new kind of material, although not manual labor. The previous forms of such labor were described in the XIX century by K. Marx as scientific, creative labor, which he called general work. This form of labor does not submit entirely to the laws of capitalist production.

The expansion of the universal type of labor - general work - in information society does not bring about any "dematerialization" of labor activity. The creation of a new form of material being - virtual reality, abstract material structures - has led to a broad extension of a new form of material labor which does not coincide with traditional manual labor. It has only formal resemblance to mental labor like the first previous forms of general work (universal labor) discovered by K. Marx had. 


\section{New Phenomena in Everyday Life}

The creation of virtual reality gives birth to substantial, probably revolutionary changes in social consciousness and everyday life which have not been completed yet and therefore cannot be evaluated completely. These replacements are closely connected with a higher level of people informing and the availability of information, which changes the psychology of interpersonal contacts and, as a result, new channels of intercommunication among people appear. These channels form a modern type of personality with new characteristics of sense perception and abstract thinking, which demands special investigations by means of psychology, sociology, theory of culture and some other humanities.

The development of universal labor can stimulate some new processes in public life. The position of the traditional working class may undergo complex changes. At first sight the workers of manual labor are to some extent replaced by mental workers. But the Marxist approach demonstrates that general work which draws in more and more non-manual workers creates a large group of people who seem to be brain workers but, in fact, produce a special material product - software, abstract material structures, etc. This new ally of the traditional working class can use some special modes of class struggle with broad opportunities. For example, N. Dyer-Witheford writes "that capital, in developing its media apparatus, has let the genie out of the bottle..." [7, p. 248]. A multiplicity of social movements now is visible to everyone and begins to interconnect. "New information technologies therefore appear not just as instruments for the circulation of commodities, but simultaneously as channels for the circulation of struggle" [7, p. 248]. These changes in social class interaction are also a product of general work which operates with abstract material structures in material virtual reality.

There appear serious changes and challenges in new transformations of labor and the ways of personality development. In a popular Russian philosophical journal E. Agazzi wrote about degradation of various human abilities, with mental arithmetic one being among them. This degradation is deeply connected with using new equipment and technologies. "We must not ignore gaining general skills and abilities which are not directed to some concrete purposes but only makes contribution to the formation of an intellectually mature personality" [1, p. 15]. A question about complicated relations between different historic forms of labor is put here. Russian philosophers mention that not only in mental sphere but in the sphere of manual labor and in interconnection of these forms of labor as well it is important to find some balance between its simple and complicated types. In the education process a tendency to ignore the simple forms of manual labor appears in Russian schools. Sometimes it is declared that in the computer age it is useless to teach children any manual work because people have to be ready for computer labor only. But investigations in psychology show that even in the information age simple forms of physical, manual labor remain important in general education and training. For example, the experiments with children show that simple manual labor helps them to achieve self-confidence and to meet the needs of creation [3, p. 159]. IT training appears to be more successful if children combine it with some other forms of activity: tasks with paperwork, realization of algorithms and group projects [17, pp. 601-605]. V.V. Orlov and T.S. Vasileva summarize this problem from the point of view of philosophy: "It is very difficult to form the abilities to material and mental activity without developing the ability to work manually - an initial form of labor, determined directly by the physical nature of humans. The development of these abilities allows them not only to reveal other abilities but even to accelerate their formation. The successful interaction of humans with a computer proves to be impossible without a well-developed hand because the ability to work mentally is based on the ability to work manually... Consequently, the main historic forms of labor have to be included into a modern system of humans training for labor" [19, p. 166]. Computer labor development initiates therefore deep changes not only in the production system but in the system of education as well.

\section{Summary and Concluding Remarks}

It is possible to conclude that the analysis of information society may be carried out with the help of Marxist methodology which includes studying the basic processes in the substance of the social system. The conceptions of computer labor as a form of material general work which operates with abstract material structures and the analysis of virtual reality as a special form of objective reality created by humans may explain the most important peculiarities of information society progress.

\section{References}

1. Agazzi, E. (2012) [The Idea of Society Based on Knowledge]. Voprosy filosofii [Questions of Philosophy]. Vol. 10, pp. 3-19. (In Russ).

2. Bell, D. (1999) Gryaduschee postindustrial'noe obshchestvo [The Coming of Post-Industrial Society]. Moscow: Academia, $956 \mathrm{p}$.

3. Beloshistaya, A.V., Zhukova, O.G. (2008) [Manual Work Organization as the Way of Development of Child's motivation]. Voprosy psikhologii [Questions of Psychology]. Vol. 2, pp. 154-159. (In Russ.) 
4. Buzgalin, A.V., Kolganov, A.I. (2015) Global'nyy kapital: monografiya. V 2 t. Tom 2. Teoriya: global'naya gegemoniya kapitala i yeye granitsy («Kapital» re-loaded). Izdaniye 3 [Global Capital: monograph. In 2 vol. Vol. 2. Theory: Global Capital Hegemony and Its Limits (“Capital” Re-loaded)]. Moscow: LENAND. (In Russ.).

5. Changli, I.I. (2010) Trud. Sotsiologicheskiye aspekty teorii i metodologii issledovaniya: monografiya. Izdaniye 4 [Labor. Sociological aspects of theory and methodology of study: monograph. Ed. 4]. Moscow: TsSP and M, 608 p. (In Russ.)

6. Dlugach, T.B. (2015) Marks: vchera i segodnya [Marx: Yesterday and Today. Part II]. Voprosy filosofii [Questions of Philosophy]. Vol. 1, pp. 23-31. (In Russ.).

7. Dyer-Witheford, N. Cyber-Marx: Cycles and Circuits of Struggle in High Technology Capitalism: monograph. Available at: http://www.fims.uwo.ca/people/facul-ty/dyerwitheford/index.htm (accessed 30.01.2019).

8. Inozemtsev, V.L. (2000) Sovremennoye postindustrial'noye obshchestvo: yego priroda, protivorechiya i perspektivy [The Modern Post-Industrial Society: Its Nature, Contradictions and Perspectives]. Moscow: Logos, 304 p. (In Russ.).

9. Lenin, V.I. (1907) Materializm i empiriokrititsizm. Polnoye sobraniye sochineniy [Materialism and EmpirioCriticism. Complete Works]. Ed. 5. Vol. 18. Moscow: Progress Publishers, pp. 7-384. (In Russ.)

10. Marx, K. (1986) Capital. Vol. 1. Moscow: Progress Publishers, 767 p.

11. Marx, K., Engels, F. Economic Manuscripts of 1857-1858 (First Version of Capital) (1986). Collected Works. Vol. 28. Economic Works. 1857-1861. Moscow: Progress Publishers and International Publishers, pp. 5-561.

12. Marx, K., Engels, F. (1986) Economic Manuscripts of 1857-1858 (First Version of Capital). Collected Works. Vol. 29. Economic Works. 1857-1861. Moscow: Progress Publishers and International Publishers, pp. 5-550.

13. Masuda, Y. (1981) The Information Society as Post-Industrial Society. Washington, DC: World Future Society, $171 \mathrm{p}$.

14. Orlov, S.V. (2103) Virtual'naya real'nost' kak novaya forma material'nogo bytiya. Filosofiya i gumanitarnyye nauki v informatsionnom obshchestve (setevoy zhurnal) [Virtual Reality as a New Form of Material Being. Philosophy and Humanities in Information Society (net journal)]. Vol.2. Available at: http://fikio.ru/wpcontent/uploads/2013/06/Filosofija-i-gumanitarnyie-nauki-v-informatsionnom-obschestve-2013-02.pdf (accessed 30.01.2019) (In Russ.)

15. Orlov, V.V., Vasileva, T.S. (2005) Filosofiya ekonomiki [Philosophy of Economics]. Perm: Izdatelstvo permskogo universiteta, 264 p. (In Russ.)

16. Orlov, V.V. (2012) Osnovy filosofii. V 2 chasti. Chast' 1: Obshchaya filosofiya. Izdaniye 5 [Fundamentals of Philosophy. In 2 parts. Part 1: General Philosophy. Ed. 5]. Perm: Permskiy Gosudarstvenniy Nationalniy Issledovatelskiy Universitet, 231 p. (In Russ.)

17. Rogozkina, I.B., Kushnirenko, A.G. (2011) PictoMir: Teaching Programming Concepts to Preschoolers with a New Tutorial Environment. Procedia - Social and Behavioral Sciences. 28, pp. 601-605.

18. Sayers, S. (2007) The Concept of Labor: Marx and His Critics. Science and Society. Vol. 71, No. 4, pp. 431-483.

19. Vasileva, T.S., Orlov, V.V. (2011) Sotsial'naya filosofiya [Social Philosophy]. Perm: Permskiy Gosudarstvenniy Universitet, 352 p. (In Russ.)

Information about the authors:

Sergei Vladimirovich Orlov, Doctor of Philosophy, Professor of History and Philosophy Department, SaintPetersburg State University of aerospace Instrumentation, Saint-Petersburg, Russia

e-mail: orlov5508@rambler.ru

Nina Andreevna Dmitrenko, Candidate of Pedagogical Sciences, Associate Professor, Director of Language Studies Center, Saint Petersburg National Research University of Information Technologies, Mechanics and Optics, Saint-Petersburg, Russia

e-mail: nadmitrenko@corp.ifmo.ru

The paper was submitted: 10.02 .2019 .

Accepted for publication: 08.04.2019.

The authors have read and approved the final manuscript.

Информация об авторах:

Сергей Владимирович Орлов, доктор философских наук, профессор кафедры истории и философии, Санкт-Петербургский государственный университет аэрокосмического приборостроения, Санкт-Петербург, Россия

e-mail: orlov5508@rambler.ru 
Нина Андреевна Дмитренко, кандидат педагогических наук, доцент, директор учебно-лингвистического центра, Санкт-Петербургский национальный исследовательский университет информационных технологий, механики и оптики, Санкт-Петербург, Россия

e-mail: nadmitrenko@corp.ifmo.ru

Статья поступила в редакцию 10.02.2019; принята в печать 08.04.2019.

Авторы прочитали и одобрили окончательный вариант рукописи. 